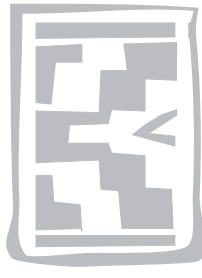

\title{
Intramammary antibiotic withdrawal periods for dairy goats compared to those for dairy cattle
}

\author{
I.M. PETZER ${ }^{1}$, E.F. DONKIN², E. DU PREEZ1 ${ }^{1}$, J. KARZIS ${ }^{1}$, T.J. VAN DER SCHANS ${ }^{1}$, \\ J.C. WATERMEYER ${ }^{1}$ and R. VAN REENEN ${ }^{1}$
}

\begin{abstract}
PETZER, I.M., DONKIN, E.F., DU PREEZ, E., KARZIS, J., VAN DER SCHANS, T.J., WATERMEYER, J.C. \& VAN REENEN, R. 2008. Intramammary antibiotic withdrawal periods for dairy goats compared to those for dairy cattle. Onderstepoort Journal of Veterinary Research, 75:255-260

This study investigated the withdrawal periods (WP) of two intramammary antibiotics Cloxamast LC (Intervet SA) and Spectrazol Milking Cow (Schering-Plough Animal Health) in dairy goats and compared them to those recommended for use in cattle.

The WP for Cloxamast LC, measured by the Thermo Resistant Inhibitory Substances (TRIS) test, was $60 \mathrm{~h}$ in composite samples, $56 \mathrm{~h}$ in udder half samples, and the dye was visible for up to $56 \mathrm{~h}$. The WP was significantly shorter than the $72 \mathrm{~h}$ recommended WP for use in cattle. It was however significantly longer when the $24 \mathrm{~h}$ safety margin $(48 \mathrm{~h}$ ) was subtracted from the recommended WP for cattle. For Spectrazol Milking Cow the antibiotics could be detected by the TRIS test for $61 \mathrm{~h}$ in composite samples and $59 \mathrm{~h}$ in udder half samples. This did not differ significantly from the recommended $60 \mathrm{~h}$ WP for cattle. However, it was significantly longer than that recommended for use in cattle without the $24 \mathrm{~h}$ safety margin.

There was no significant difference in WP between infected and non-infected udder halves, while there was a weak positive correlation between WP and stage of lactation $\left(R^{2}=0.253\right)$. There was a moderate positive correlation $\left(R^{2}=0.583\right.$ ) between the TRIS test and the presence of dye in milk in udder half samples and between WP in both udder half and composite milk samples $\left(R^{2}=0.456\right)$. Weak to moderate positive correlations were present between milk yield and the WP in both udder half $\left(R^{2}=0.414\right)$ and composite $\left(R^{2}=0.262\right)$ milk samples. Significant differences $(P<0.001)$ were also observed between the milk yield of udder halves with and without palpable udder damage and between samples that tested TRIS positive and negative on both composite $(P=0.008)$ and udder half samples $(P<0.001)$. There was no significant difference between the milk yield of samples with or without dye. There was a significant difference in milk yield between infected and non-infected udder halves $(P=0.054)$ and a weak negative correlation between milk yield and stage of lactation $\left(R^{2}=-0.379\right)$.
\end{abstract}

Keywords: Antibiotic withdrawal periods, goat milk, intramammary treatment

* Author to whom correspondence is to be directed. E-mail: inge-marie.petzer@up.ac.za

1 Department of Production Animal Studies, Faculty of Veterinary Science, University of Pretoria, Private Bag X04, Onderstepoort, 0110 South Africa

2 Department of Animal and Wildlife Sciences, Faculty of Natural and Agricultural Sciences, University of Pretoria, Pretoria, 0002 South Africa

Accepted for publication 10 June 2008-Editor

\section{INTRODUCTION}

There is an increasing demand for goat milk for cheese-making and for use by children intolerant to milk from other sources (Jaubert \& Kalantzopoulos 1996). The growing population of southern Africa needs high-quality protein to reduce malnutrition, especially in children. Milk production from dairy goats is one source that should be developed (Don- 
kin 1997). There are many advantages in the use of dairy goats rather than cattle for subsistence production by smallholder farmers. Dairy cattle, as the traditional source of milk, are expensive to keep and require sophisticated feeding and management to be productive. In contrast, dairy goats are more appropriate to the needs of subsistence production and their use would be in harmony with the concept of household economy (Low 1986). Goats are cheaper, require less food, produce appropriate quantities of milk, breed at a younger age, have multiple births, are more easily handled by women and children, represent a smaller loss in the event of death, and produce a carcass of appropriate size for a household's needs (Devendra \& Burns 1983).

One of the most threatening diseases to dairy goats is mastitis (Smith \& Sherman 1994). At present, mastitis in goats is being treated with the antibiotic preparations used for treating bovine mastitis, in the assumption that antibiotic milk withdrawal periods are similar for goats and cattle (Debackere 1995). However, limited research has shown that residues persist for a longer period in goat milk than in milk from cattle (Bangen, Skjerve, Grave \& Soli 1992; Karzis 2005).

Antibiotic residues in goat milk may pose a serious health hazard to humans, as anaphylactic and allergic reactions may occur. There is also the danger of development of resistant strains of bacteria and production of cheese can be compromised by the presence of antibiotic residues in the milk (Smith \& Sherman 1994).

It is necessary to establish appropriate WP times for intramammary antibiotics used in dairy goats to prevent hazard to human health and secondary production losses. Thus, the objective of this study was to identify withdrawal periods (WPs) in dairy goats and compare them to those for dairy cattle.

\section{MATERIALS AND METHODS}

\section{Experimental animals}

A trial was conducted at the Faculty of Veterinary Science, University of Pretoria at Onderstepoort, during the summer months using the herd of milk goats of the Faculty's Teaching Animal Unit (OTAU). The trial was conducted over a period of 9 days, using 29 lactating Saanen goats of which 12 were in early lactation, two in mid-lactation and 15 in late lactation. The goats were relatively low producers, giving less than $1.3 \ell$ per day.
Results of clinical udder examination, milk yield, age and stage of lactation were evaluated prior to the selection of experimental animals by the principle of pairing. One goat of each pair was then allocated to either of the treatment groups or the control group. The last pair had no control. Goats were identified by temporary markings.

A clinical examination of the mammary parenchyma was performed post milking in the lactating goats according to the method described by Giesecke \& Van den Heever (1974) and Giesecke, Du Preez \& Petzer (1994).

\section{Sampling}

The goats were milked at 12-hourly intervals, using a milking machine with a low milk line set at a system vacuum of $36 \mathrm{kPa}$ and a pulsation rate of $74 \mathrm{per}$ min. At each milking, foremilk udder half samples were taken aseptically (Giesecke et al. 1994), followed by conductivity readings and the California Milk Cell Test (CMCT) (Karzis 2005). Udder halves were milked separately and milk yields were recorded for trial times $-24 \mathrm{~h}$ to $+108 \mathrm{~h}$ during the trial. Composite milk samples were taken from the total volume of milk obtained from each udder half for the determination of evaluation by the Thermo-Resistant Inhibitory Substances (TRIS) test. Sampling continued until the Somatic Cell Count (SCC) returned to baseline values and there were at least two consecutive, negative TRIS test results for all goats.

\section{Antibiotic treatment}

\section{Products investigated}

The two antibiotic intramammary products used in this trial were selected because they are commonly used broad-spectrum preparations formulated for use in dairy cattle. Cloxamast LC (G2018) (Intervet SA), containing $200 \mathrm{mg}$ cloxacillin, $75 \mathrm{mg}$ ampicillin and a blue dye was used to treat ten goats in their left udder halves (T1) leaving the right udder halves as untreated intra-udder controls (C1). Another ten goats were similarly treated using Spectrazol Milking Cow (83/594) (Schering-Plough Animal Health), containing $250 \mathrm{mg}$ cefuroxime, also only in the left udder halves (T2) leaving right udder halves as untreated intra-udder controls (C2). Nine goats were not treated at all and were used as untreated controls.

\section{Administration of antibiotics}

The entire content of the syringe containing the medication was inserted aseptically into the left ud- 
der half of each of the 20 goats. Three treatments were administered at 12-hourly intervals.

\section{Laboratory procedures}

Laboratory procedures were conducted at the milk laboratory of the Department of Production Animal Studies, Faculty of Veterinary Science, University of Pretoria.

\section{Visual inspection of milk samples}

All milk samples were examined for the presence of floccules, a watery consistency and discolouration. The presence or absence of blue dye in the milk was noted for samples treated with Cloxamast LC.

\section{Microbiology}

Milk samples were cultured on bovine blood tryptose agar (BTA) (Columbia Blood Agar Base, CM331, Oxoid plus defibrinated bovine blood), which supports the growth of most mastitogenic bacterial pathogens. Inoculated agar plates were incubated for $18-24 \mathrm{~h}$ at $37 \pm 1^{\circ} \mathrm{C}$, evaluated for growth, and reincubated and re-read after a further $24 \mathrm{~h}$ (Sandholm 1995).

\section{Thermo-resistant inhibitory substances}

The TRIS test was carried out on all milk samples to determine the presence of antibiotic residues and other heat stable inhibitory substances present (Karzis 2005).

\section{Somatic cell counting}

A Fossomatic 90 (The Rhine Ruhr Group) was used to perform SCC.

\section{Delvo test}

The Delvo test was performed in duplicate on udder half samples (Gist-Brocades BSD B.V., Dairy Ingredienta Group, The Netherlands).

\section{Data management}

\section{Criteria for assessing efficacy}

When TRIS test results were negative for two consecutive samplings, it was assumed that no more antibiotic residues were present. All WP results were measured until the first time that the antibiotic residues were negative (not present) according to the TRIS test performed on composite and half milk samples, and for the presence or absence of dye evaluated in half milk samples.
Statistical analyses

All data were entered and stored in Microsoft Excel. Data were statistically analysed using the statistical program GenStat.

\section{RESULTS AND DISCUSSION}

Withdrawal period of intramammary antibiotics in goats compared to WP recommended for use in cattle with or without the $24 \mathrm{~h}$ safety margin.

Withdrawal periods as recommended for use in cattle have a 24 h safety margin added as for registration, while this research does not have this $24 \mathrm{~h}$ safety margin added. As the raw data from the trials carried out in order to determine this WP in cattle were not available, an estimated period for cattle was determined by subtracting a $24 \mathrm{~h}$ period from the WP recommended for use in cattle. This estimated WP for cattle was also compared to the WP of intramammary antibiotics used in goats (Table 1). There were significant differences in all the onesample t-tests between WP for goats, compared to WP recommended for use in cattle without the $24 \mathrm{~h}$ safety margin. Not all, however, were significant when compared to WP as recommended for use in cattle (Table 1). These results are in agreement with those of found by Karzis (2005).

\section{Withdrawal period of Cloxamast LC used in goats compared to that recommended for use in cattle}

Cloxamast LC contains ampicillin and cloxacillin (beta-lactam penicillins), which are both bactericidal and time dependant (Le Roux 2004). Zeng, Escobar \& Brown-Crowder (1996) showed that WP in goats according to the Penzyme Test, the Delvo test $P$ and the TRIS test were $72 \mathrm{~h}$ for Penicillin $\mathrm{G}$ and 120 $\mathrm{h}$ for Cephapirin. In cattle the TRIS test is routinely used for the detection of antibiotic residues. A negative TRIS test is an indication of the Maximum Residue Limits (MRLs) and safe tolerance levels for antibiotic residues in milk as fixed by Codex Alimentarius, European Community (EC)-Regulations and the United States Food and Drug Administration (USFDA). The MRLs (EC) for ampicillin, and cloxacillin were $4 \mu \mathrm{g} / \mathrm{kg}$ and $30 \mu \mathrm{g} / \mathrm{kg}$, respectively, and MRLs (Codex) for ampicillin and cloxacillin were both 4 rg/kg (Honkanen-Buzalski \& Reybroeck 1997).

The withdrawal periods as measured by TRIS on composite samples (60 h) and on udder half samples (56 h) as well as WPs, as measured by colour 
dye $(56 \mathrm{~h})$, were significantly shorter than the WP recommended for use in cattle $(72 \mathrm{~h})$. However, when the $24 \mathrm{~h}$ safety period was subtracted (48 h) from the recommended WP in cattle they were longer (Table 1). Karzis (2005) found the WP in goats treated with Curaclox LC to be $58 \mathrm{~h}$ (for low and high producers considered together) but when considered separately, to be $74 \mathrm{~h}$ for low producers and $42 \mathrm{~h}$ for high producers (measured by TRIS). Cura- clox LC has the same active ingredients as Cloxamast LC.

\section{Withdrawal period of Spectrazol Milking Cow compared to that recommended for use in cattle}

Spectrazol contains cefuroxime, a second-generation beta-lactam cephalosporin, which is bacterio-

TABLE 1 Withdrawal period (WP) of intramammary antibiotics in goats compared to the WP recommended for use in cattle with or without the $24 \mathrm{~h}$ safety margin (one sample t-tests)

\begin{tabular}{|l|l|l|l|l|}
\hline $\begin{array}{l}\text { Trials and products } \\
\text { used }\end{array}$ & $\begin{array}{l}\text { Withdrawal periods } \\
\text { measured by } \\
\text { different methods }\end{array}$ & $\begin{array}{l}\text { Mean } \pm \text { Standard } \\
\text { Deviation } \mathbf{h} \text { ) } \\
\text { withdrawal period } \\
\text { recommended for } \\
\text { use in cattle }\end{array}$ & $\begin{array}{l}\text { Probability withdraw- } \\
\text { al period recom- } \\
\text { mended for use in } \\
\text { cattle }\end{array}$ & $\begin{array}{l}\text { Probability withdraw- } \\
\text { al period recom- } \\
\text { mended for use in } \\
\text { cattle }-24 \mathbf{h}\end{array}$ \\
\hline Cloxamast LC (T1) & $\begin{array}{l}\text { WP TRIS composite } \\
\text { WP dye } \\
\text { WP TRIS half }\end{array}$ & $\begin{array}{l}60 \pm 5.37 \\
56 \pm 6.05\end{array}$ & $\begin{array}{l}P<0.001 \\
P< \pm 0.001 \\
P<0.001\end{array}$ & $\begin{array}{l}P<0.001 \\
P=0.002\end{array}$ \\
\hline Spectrazol (T2) & WP TRIS composite & $61 \pm 3.80$ & $\begin{array}{l}P=0.343 \\
P=0.591\end{array}$ & $P<0.001$ \\
& WP TRIS half & $59 \pm 6.81$ & $P<0.001$ \\
\hline
\end{tabular}

$P$ is significant at the $5 \%$ level $(P<0.05)$

TABLE 2 Withdrawal periods (WP) measured by different methods between infected and non-infected udder halves (Cloxamast; T1) (two-sample t-tests)

\begin{tabular}{|l|l|l|l|l|l|l|}
\hline \multirow{2}{*}{ Variate } & \multicolumn{5}{|c|}{ Withdrawal period (WP) (h) } & \multirow{2}{*}{} \\
\cline { 3 - 6 } & \multirow{2}{*}{ Group factor } & Infected udder halves & \multicolumn{2}{l|}{ Non-infected udder halves } & \multirow{2}{*}{ Probability } \\
\cline { 3 - 6 } & & $\begin{array}{l}\text { Number of } \\
\text { samples }\end{array}$ & Mean \pm SD & $\begin{array}{l}\text { Number of } \\
\text { samples }\end{array}$ & Mean \pm SD & \\
\hline WP TRIS composite & Bacteria & 5 & $62 \pm 5.37$ & 16 & $60 \pm 4.38$ & $P=0.322$ \\
WP Dye & Bacteria & 3 & $52 \pm 6.93$ & 8 & $57 \pm 5.56$ & $P=0.241$ \\
WP TRIS half & Bacteria & 5 & $58 \pm 5.37$ & 17 & $57 \pm 6.75$ & $P=0.899$ \\
\hline
\end{tabular}

For an accurate two-sample t-test, a minimum of five samples per group is necessary. Therefore, the above test is an indication, but there are too few samples for an accurate test

TABLE 3 Differences in milk yield $(\mathrm{m} \ell)$ between udder halves with or without udder damage and udder halves with or without bacteria

\begin{tabular}{|l|l|l|l|l|}
\hline \multicolumn{2}{|l|}{ Udder palpation } & \multicolumn{2}{l|}{ Udder damage } & \multirow{2}{*}{ Probability } \\
\hline \multicolumn{2}{|l|}{ No udder damage } & $n$ & Mean \pm SD & \\
\hline $\boldsymbol{n}$ & Mean \pm SD & 256 & $331.1 \pm 307.6$ & $P<0.001$ \\
\hline Bacteria & $451.1 \pm 296.7$ & \multicolumn{2}{|l|}{ Probability } \\
\hline Infected udder halves & Non-infected udder halves & \\
\hline $\boldsymbol{n}$ & Mean \pm SD & $n$ & Mean \pm SD & P \\
\hline 217 & $385.7 \pm 304.8$ & 940 & $429.2 \pm 297.7$ & 0.054 \\
\hline
\end{tabular}

$P$ is significant at the $5 \%$ level $(P<0.05)$ 
cidal and time dependant (Le Roux 2004). Its $\mathrm{MRL}$ (s) as fixed by the Codex Alimentarius for Cephalosporins is $100 \mu \mathrm{g} / \mathrm{kg}$ (Honkanen-Buzalski \& Reybroeck 1997). In this trial WP measured by TRIS on both composite ( $61 \mathrm{~h})$ and udder half samples $(59 \mathrm{~h})$ proved not to be significantly longer than recommended for use in cattle $(60 \mathrm{~h})$ (Table 1). This finding differed from the results obtained by Karzis (2005) where a WP of $96 \mathrm{~h}$ was measured with Spectrazol Milking Cow. In both the latter trials goats had low milk yields (less than $1.3 \ell$ per day) while goats in this trial were at different stages of lactation. Withdrawal periods on both composite and half samples proved to be significantly longer than those recommended for use in cattle without the $24 \mathrm{~h}$ safety margin (36 h) (Table 1).

\section{Differences in WP between infected and non-infected udder halves treated with Cloxamast LC}

There were no significant differences between WP as measured by the presence of colour dye and TRIS for both composite and udder half milk sam- ples between infected and non-infected udder halves treated with Cloxamast LC (Table 2).

\section{Factors affecting milk yield}

There was a significant difference $(P<0.001)$ in milk yield between udders with and without clinical damage (Table 3 ) and a moderate significant difference in milk yield at the $5 \%$ level between infected and non-infected udder halves $(P=0.054)$. A significant difference in milk yield was also measured between udders that were positive and negative for TRIS test on composite $(P=0.008)$ and udder half samples $(P<0.001)$, but there was no significant difference of milk yield for samples with or without the presence of colour dye (Table 4).

\section{Correlations of WP, milk yield and stage of lactation}

There was a moderately positive correlation between WP as measured by TRIS and colour dye in udder half milk samples $\left(R^{2}=0.583\right)$ and between TRIS test results for udder half and composite milk sam-

TABLE 4 Differences in milk yield $(\mathrm{m} \ell)$ between udder halves with positive and negative TRIS composite and udder half samples and udder half samples with or without blue dye

\begin{tabular}{|c|c|c|c|c|c|}
\hline \multirow{3}{*}{ TRIS } & \multicolumn{4}{|c|}{ TRIS test } & \multirow{3}{*}{ Probability } \\
\hline & \multicolumn{2}{|c|}{ TRIS negative } & \multicolumn{2}{|c|}{ TRIS positive } & \\
\hline & $n$ & Mean \pm SD & $n$ & Mean \pm SD & \\
\hline $\begin{array}{l}\text { TRIS composite } \\
\text { TRIS half }\end{array}$ & $\begin{array}{l}557 \\
503\end{array}$ & $\begin{array}{l}472.4+316.1 \\
478.5 \pm 311.3\end{array}$ & $\begin{array}{l}118 \\
143\end{array}$ & $\begin{array}{l}389.0+276.7 \\
343.0 \pm 269.7\end{array}$ & $\begin{array}{l}P=0.008 \\
P<0.001\end{array}$ \\
\hline \multirow{4}{*}{ Dye } & \multicolumn{4}{|c|}{ Udder half milk samples of goats treated with Cloxamast LC } & \multirow{3}{*}{ Probability } \\
\hline & \multicolumn{2}{|c|}{ Blue dye present } & \multicolumn{2}{|c|}{ Blue dye absent } & \\
\hline & $n$ & Mean \pm SD & $n$ & Mean \pm SD & \\
\hline & 50 & $421.7 \pm 290.6$ & 1105 & $420.7 \pm 300.1$ & $P=0.981$ \\
\hline
\end{tabular}

$\mathrm{P}$ is significant at the $5 \%$ level $(P<0.05)$

TABLE 5 Correlations between tests relating to treatment with Cloxamast LC \& Spectrazol Milking Cow

\begin{tabular}{|c|c|c|c|c|c|c|c|c|c|}
\hline Withdrawal period (WP) (Dye) & 1 & 1.000 & & & & & & & \\
\hline Log SCC & 2 & 0.521 & 1.000 & & & & & & \\
\hline WP(TRIS) composite samples & 3 & 0.000 & 0.051 & 1.000 & & & & & \\
\hline WP(TRIS) udder half samples & 4 & 0.583 & 0.440 & 0.456 & 1.000 & & & & \\
\hline Conductivity (colour) & 5 & -0.408 & -0.109 & 0.000 & 0.272 & 1.000 & & & \\
\hline Conductivity (scores) & 6 & -0.379 & -0.015 & -0.069 & 0.221 & 0.902 & 1.000 & & \\
\hline CMCT score & 7 & 0.000 & 0.274 & 0.707 & 0.645 & 0.527 & 0.440 & 1.000 & \\
\hline \multirow[t]{2}{*}{ Milk yield } & 8 & 0.494 & 0.546 & 0.262 & 0.414 & -0.495 & -0.477 & 0.123 & 1.000 \\
\hline & & 1 & 2 & 3 & 4 & 5 & 6 & 7 & 8 \\
\hline
\end{tabular}

Degrees of freedom $=8$ 
ples $\left(R^{2}=0.456\right)$ (Table 5). Weak to moderately positive correlations were present between milk yield and WP $($ TRIS $)$ in udder half $\left(R^{2}=0.414\right)$ and composite $\left(R^{2}=0.262\right)$ milk samples. This finding is not in agreement with the research reported by Karzis (2005), where increased milk yield was associated with a significantly shorter WP. A weak negative correlation was found between milk yield and stage of lactation $\left(R^{2}=-0.379\right)$.

\section{The inaccuracy of the Delvo test}

In this research the Delvo test was carried out in duplicate on both composite and udder half milk samples. These results did not correspond at all with the TRIS results, or with the relevant treatment times. Zeng et al. (1996), however did report on the successful use of the Delvo test in goat milk.

\section{CONCLUSIONS}

There were important differences between WP recommended for use in cattle and those found in goats, which indicates the urgency for testing the WP of intramammary antibiotics for goats. Udder half samples gave more accurate results for the TRIS test than composite milk samples. Moderately positive correlations were shown between WP and colour dye and between WP and milk yield measured by TRIS. The presence of colour dye in the milk in udder halves treated with Cloxamast LC showed some usefulness of the dye as an indication of the presence of antibiotic residues in milk. The WP was affected by stage of lactation, milk yield and goat breed. In this study, only clinically healthy goats were used. Milk yield was negatively affected by clinical udder damage (assessed by palpation), udder infection and an increase in the stage of lactation. There was a positive correlation between milk yield and WP, which was not in agreement with that obtained in a previous study (Karzis 2005).

Further research on WP of intramammary antibiotics in dairy goats should take into account the breed, stage of lactation, parity, milk yield, and status of infection of the udder. Goats both with and without clinical mastitis should be used. The insertion of a whole tube of intramammary antibiotic into udder halves may lead to an increased antibiotic concentration in the udder. Commercially-driven studies are encouraged to determine whether it would be a viable proposition to design tubes, not only containing smaller volumes of contents with smaller quantities of antibiotics but also with smaller and shorter tips to minimize the risk of teat canal damage, especially for use in goats.

\section{REFERENCES}

BANGEN, M., SKJERVE, E., GRAVE, K. \& SOLI, N.E. 1992. Prescribing of drugs for food producing animals in Norway. Information about withdrawal times. Journal of Veterinary Pharmacology and Therapeutics, 15:180-187.

DEBACKERE, M. 1995. Pharmacokinetics and pharmacodynamics of antimicrobials in relation to their residues in milk. Proceedings of a Symposium on Residues of Antimicrobial Drugs and other Inhibitors in Milk, Kiel, Germany, 1995: 41.

DEVENDRA, C. \& BURNS, M. 1983. Goat production in the tropics. Slough: Commonwealth Agricultural Bureaux.

DONKIN, E.F. 1997. Productivity and diseases of Saanen, Indigenous and Crossbred goats on zero grazing. Ph.D. thesis, Medical University of Southern Africa.

GIESECKE, W.H. \& VAN DEN HEEVER, L.W. 1974. A guide to the testing of stock remedies (Act 36/1947) for the treatment and control of septic mastitis of cows (Mastitis Remedies). Department of Agricultural Technical Services, RSA (Technical Communication, no. 123).

GIESECKE, W.H., DU PREEZ, J.H. \& PETZER, I.M. 1994. Practical mastitis control in dairy herds. Durban: Butterworths.

HONKANEN-BUZALSKI, T. \& REYBROECK, W. 1997. Residues and contaminants in milk and milk products: Antimicrobials (International Dairy Federation, Special Issue 9701).

JAUBERT, G. \& KALANTZOPOULOS, G. 1996. Quality of goat milk for cheese and other products. Proceedings of the $6^{\text {th }}$ International Dairy Conference on Goats, Beijing, China, 1996: 274-281.

KARZIS, J. 2005. Intramammary antibiotics in dairy goats: Withdrawal periods and tissue tolerance. M.Sc. thesis, University of Pretoria.

LE ROUX, L. 2004. Antibiotika: Antibiotiese klassifikasie-kliniese gebruik van antimikrobiale middels (3), Livestock Health and Production Review, 6:5-9.

LOW, A. 1986. Agricultural development in Southern Africa: Farm household economics and the food crisis. London: James Currey.

SANDHOLM, M. 1995. The bovine udder and mastitis. Isolation and identification of pathogens from milk, edited by M. Sandholm, T. Honkanen-Buzalski, L. Kaartinen \& S. Pyorala. Jyväskylä: Gummerus Kirjapaino Oy.

SMITH, M.C. \& SHERMAN, D.M. 1994. Goat medicine. Baltimore: Lippincott, Williams \& Wilkins.

ZENG, S.S., ESCOBAR, E.N. \& BROWN-CROWDER, I. 1996. Evaluation of screening tests for detection of antibiotic residues in goat milk. Small Ruminant Research, 21:155-160. 